Tersedia online di: http://ejournal-balitbang.kkp.go.id/index.php/JP
e-mail:jurnalpari@gmail.com
JURNAL PARI
volume 6 Nomor 1 Juli 2020
p-ISSN: 2502-0730
e-ISSN : 2549-0133

\title{
KEBERLANJUTAN PERPUSTAKAAN DAN KEPUSTAKAWANAN di LINGKUNGAN LIPI KAWASAN JAKARTA
}

\author{
Rochani Nani Rahayu' dan Yupi Royani'2, \\ Pusat Data dan Dokumentasi IImiah LIPI, Lembaga IImu Pengetahuan Indonesia, Jakarta \\ Diterima Tanggal : 2Maret 2020 Diterima setelah perbaikan : 13 Juli 2020 \\ Disetujui terbit : 20 Juli 2020
}

\begin{abstract}
ABSTRAK
Di lingkungan Lembaga IImu Pengetahuan Indonesia (LIPI) terdapat perpustakaan yang berada pada masing - masing satuan kerja. Dalam beberapa tahun ini keberadaan perpustakaan di lingkungan satuan kerja LIPI mulai dipertanyakan dan dipermasalahkan karena pemustaka yang datang secara langsung sudah mulai berkurang. Penelitian ini bertujuan untuk mengetahui persepsi kepala satuan kerja serta para peneliti di lingkungan LIPI Kawasan Jakarta tentang keberadaan dan keberlanjutan perpustakaan dan kepustakawanan di lingkungan LIPI Jakarta. Digunakan metode kualitatif dilengkapi dengan wawancara mendalam. Penelitian dilakukan terhadap Kepala Satuan Kerja serta para peneliti di lingkungan LIPI Jakarta, meliputi PDDI, Pusat Penelitan Politik, Pusat Peneltian Ekonomi, Pusat Penelitian Kemasyarakatan dan Kebudayaan, Pusat Penelitian Kependudukan, LIPI Press, Pusat Penelitian Oseanografi, Pusat Kebijakan dan Manajemen Iptek dan Inovasi dengan jumlah responden sebanyak 30 orang. Hasil dan kesimpulan menunjukkan bahwa Perpustakaan tetap diperlukan, karena informasi yang ada di perpustakaan merupakan harta kekayaan intelektual yang harus dipelihara dan dilestarikan agar bisa diwariskan untuk generasi mendatang serta dikembangkan agar didapat kekayaan intelektual yang baru. Namun disarankan agar perpustakaan dilengkapi dengan, sarana dan prasarana yang lengkap dan nyaman, serta diharapkan pustakawan meningkatkan kompetensi agar dapat memberikan layanan dengan lebih baik.
\end{abstract}

Kata kunci: Pustakawan; Perpustakaan; Kepustakawanan; Perpustakaan Khusus; Peneliti.

\begin{abstract}
Within the Indonesian Institute of Sciences (LIPI) there are libraries located in each work unit. In recent years the existence of libraries in the LIPI work unit environment has begun to be questioned and questioned because users who come directly have begun to decrease. This study aims to determine the perceptions of the head of the work unit as well as researchers in the Jakarta LIPI environment about the existence and sustainability of libraries and librarians in the Jakarta LIPI environment. Used a qualitative method supplemented with in-depth interviews. The study was conducted on the Head of the Work Unit and researchers in the LIPI Jakarta, including the Center for Scientific Data and Documentation, the Center for Political Research, the Center for Economic Research, the Center for Community and Cultural Research, the Center for Population Research, LIPI Press, the Center for Oceanographic Research, the Center for Policy and Management Science and Innovation with 30 respondents. The results and conclusions show that the Library is still needed, because the information in the library is intellectual property that must be preserved and preserved so that it can be inherited for future generations and developed in order to obtain new intellectual property. However, it is recommended that the library be equipped with complete and convenient facilities and infrastructure, and it is hoped that librarians will increase their competence in order to provide better services.
\end{abstract}

Keywords: Librarian; Library; Private Library; Researcher.

Korespondensi penulis:

Gedung PDII-LIPI, Jalan Jendral Gatot Subroto No. 10, Karet Semanggi, Setiabudi, RT.6/RW.1, Kuningan Bar., Kec. Mampang Prpt., Kota Jakarta Selatan, Daerah Khusus Ibukota Jakarta 12930 email : nanipdii@yahoo.com ${ }^{1} y u p i \_r d d @ y a h o o . c o . i d^{2}$ 


\section{PENDAHULUAN}

\section{Latar Belakang}

Seperti kita ketahui bersama, di lingkungan Lembaga Ilmu Pengetahuan Indonesia (LIPI) terdapat perpustakaan yang berada pada masing - masing satuan kerja. Salah satu satuan kerja yang memiliki layanan perpustakaan adalah Pusat Dokumentasi dan Informasi IImiah (PDII- LIPI). Di dalam struktur organisasi LIPI, menurut Perka No 1 Tahun 2014, PDII LIPI tidak memiliki perpustakaan, namun pada kenyataannya PDII memberikan layanan perpustakaan, penelusuran informasi, baik yang datang secara langsung maupun tidak langsung (Email, telepon, fax, dII). Hal ini dikarenakan PDII LIPI mempunyai koleksi yang sangat lengkap dan beragam, mulai dari Buku, Jurnal, Tesis, Laporan penelitian, dll.

Disamping Perpustakaan Pusat Dokumentasi dan Informasi IImiah, LIPI juga mempunyai kawasan Perpustakaan Jakarta.Kawasan Perpustakaan Jakarta yang pada awalnya adalah kepunyaan IPSK (IImu Pengetahuan Sosial dan Kemanusiaan) Perpustakaan kedeputian IPSK terletak dilantai IV gedung PDDI - LIPI Jakarta. Koleksinya kebanyakan adalah koleksi bidang sosial. Sekarang kepustakaan IPSK tersebut sudah bergabung dengan perpustakaan PDDI - LIPI. Kedeputian IPSK dan PDDI - LIPI terdiri dari Pusat Penelitian Kemasyarakatan dan Kebudayaan, Pusat Penelitian Kependudukan, Pusat Penelitian Politik, Pusat Penelitian Ekonomi, Pusat Penelitian Kependudukan dan Pusat Penelitian Sumber Daya Regional.

Dalam beberapa tahun ini keberadaan perpustakaan di lingkungan satuan kerja LIPI tidak terkecuali di PDII mulai dipertanyakan dan dipermasalahkan karena pemustaka yang datang secara langsung sudah mulai berkurang. Hal ini diduga oleh karena informasi yang mereka cari dapat diperoleh dari sumber-sumber on line seperti jurnal online, tesis online, dll dari berbagai repositori dari instansi-instansi dan perguruan tinggi, sehingga mereka tidak perlu lagi datang ke perpustakaan. Perlu diakui di era sekarang hampir semua informasi dapat diakses secara online, bahkan banyak juga informasi yang dibutuhkan tidak berbayar. Kondisi tersebut selain terjadi di PDII, juga terjadi di perpustakaan satuan kerja lain di LIPI Pusat Penelitian Kemasyarakatan dan Kebudayaan, Pusat Penelitian Kependudukan, Pusat Penelitian Politik, Pusat Penelitian Ekonomi, Pusat Penelitian Kependudukan dan Pusat Penelitian Sumber Daya Regional.
Apabila kita merujuk kepada Undang-undang Nomor 43 Pasal 25 tentang Perpustakaan, dinyatakan bahwa Perpustakaan Khusus menyediakan bahan perpustakaan sesuai dengan kebutuhan pemustaka di lingkungannya. Selanjutnya pada Pasal 26 dinyatakan bahwa Perpustakaan Khusus memberikan layanan kepada pemustaka di lingkungannya dan secara terbatas memberikan layanan kepada pemustaka di luar lingkungannya. Oleh karena itu, sebetulnya merupakan hal yang wajar apabila Perpustakaan Khusus yang berada di bawah satuan kerja di LIPI tidak banyak dikunjungi kecuali oleh para peneliti di bidangnya, serta hanya sedikit pemustaka dari luar satuan kerja dimana perpustakaan tersebut bernaung.

Sebagai gambaran profil pustakawan di LIPI seluruhnya berjumlah sekitar 50 orang terdiri atas Pustakawan keahlian yang terdiri atas Pustakawan Utama, Pustakawan Madya, Pustakawan Muda, Pustakawan Terampil yang ditempatkan di beberapa satuan kerja di lingkungan LIPI. Apabila dibandingkan dengan jumlah peneliti LIPI yang secara keseluruhan berjumlah 1.715 orang (Pusbindiklat LIPI; 2018), artinya apabila di rata-rata setiap pustakawan melayani sebanyak 343 orang peneliti sehingga pustakawan diduga kurang maksimal dalam memberikan pelayanan kepada pemustakanya. Oleh sebab itu, diperlukan penelitian apakah perpustakaan dan pustakawan di lingkungan LIPI tersebut masih dibutuhkan.

Penelitian ini menggunakan metode kualitatif dilengkapi dengan wawancara mendalam. Seperti dikatakan oleh (Jamshed, S; 2014) bahwa wawancara mendalam merupakan salah satu pengembangan metode kualitatif. Penelitian akan dilakukan terhadap Kepala Pusat serta para peneliti di lingkungan LIPI yang tersebar di lingkungan Jakarta

\section{Rumusan Masalah}

Berdasarkan uraian latar di atas, maka rumusan masalah penelitian ini secara umum adalah sebagai berikut:

1. Apa yang dimaksud dengan perpustakaan di lingkungan LIPI Jakarta

2. Apa yang dimaksud dengan pustakawan di lingkungan LIPI Jakarta

3. Apakah perpustakaan masih dibutuhkan di lingkungan LIPI Jakarta

4. Apakah pustakawan masih dibutuhkan di lingkungan LIPI Jakarta

5. Apakah fungsi perpustakaan di lingkungan LIPI Jakarta 
6. Apakah fungsi pustakawan di lingkungan LIPI Jakarta

7. Apakah manfaat yang dirasakan dengan keberadaan perpustakaan di lingkungan LIPI Jakarta

8. Apakah manfaat yang dirasakan dengan keberadaan pustakawan di lingkungan LIPI Jakarta

9. Apakah kendala yang dihadapi dengan keberadaan perpustakaan di lingkungan LIPI Jakarta

10. Apakah kendala yang dihadapi dengan keberadaan pustakawan di lingkungan LIPI?

11. Apakah harapan yang diinginkan dengan keberadaan perpustakaan di lingkungan LIPI Jakarta

12. Apakah harapan yang diinginkan dengan keberadaan pustakawan di lingkungan LIPI Jakarta

\section{Kajian Pustaka}

\section{Perpustakaan}

Menurut American Library Association (ALA; 2010) definisi dari perpustakaan adalah sebagai berikut ." $A$ library is a collection of resources in a variety of formats that is (1) organized by information professionals or other experts who (2) provide convenient physical, digital, bibliographic, or intellectual access and (3) offer targeted services and programs (4) with the mission of educating, informing, or entertaining a variety of audiences (5) and the goal of stimulating individual learning and advancing society as a whole."

Berdasarkan beberapa definisi di atas dapat disimpulkan bahwa perpustakaan memiliki terdiri atas beberapa unsur yaitu: 1) institusi/organisasi/tempat/ bangunan/ruangan, 2) koleksi (karya rekam/karya cetak, digital, dll); 3) layanan; 4) pendidikan; 5) penelitian; 6) tempat rekreasi.

Menurut UU No 43 Tahun 2007 Tentang Perpustakaan dibedakan menjadi: 1) Perpustakaan Nasional adalah lembaga pemerintah non departemen (LPND) yang melaksanakan tugas pemerintahan dalam bidang perpustakaan yang berfungsi sebagai perpustakaan pembina, perpustakaan rujukan, perpustakaan deposit, perpustakaan penelitian, perpustakaan pelestarian, dan pusat jejaring perpustakaan, serta berkedudukan di ibukota negara ;2) Perpustakaan umum adalah perpustakaan yang diperuntukkan bagi masyarakat luas sebagai sarana pembelajaran sepanjang hayat tanpa membedakan umur, jenis kelamin, suku, ras, agama, dan status sosial-ekonomi; 3) Perpustakaan khusus adalah perpustakaan yang diperuntukkan secara terbatas bagi pemustaka di lingkungan lembaga pemerintah, lembaga masyarakat, lembaga pendidikan keagamaan, rumah ibadah, atau organisasi lain. Selanjutnya dinyatakan juga bahwa Perpustakaan khusus mempunyai fungsi menyediakan bahan perpustakaan sesuai dengan kebutuhan pemustaka di lingkungannya dan secara terbatas memberikan layanan kepada pemustaka di luar lingkungannya. Manfaat Perpustakaan di LIPI adalah mencerdaskan kehidupan bangsa melalui literasi informasi (UUD 45) Selanjutnya mengacu kepada Pasal 16 UU No 43 Tentang Perpustakaan, disebutkan bahwa berdasarkan kepemilikan maka perpustakaan dibedakan menjadi a) perpustakaan pemerintah; b) perpustakaan provinsi; c) perpustakaan kabupaten/ kota; d) perpustakaan kecamatan; e) perpustakaan desa; f) perpustakaan masyarakat; g) perpustakaan keluarga; dan $\mathrm{h}$ ) perpustakaan pribadi. Menurut ALA (2010), Perpustakaan Umum adalah perpustakaan yang melayani berbagai pemustaka dari bermacammacam kalangan, dari berbagai usia, pendidikan dan berbagai latar belakang. Berikutnya Perpustakaan Sekolah berfokus kepada pembelajaran sepanjang hayat, serta mempersiapkan anak-anak didik untuk memasuki ke jenjang pendidikan yang lebih tinggi. Biasanya perpustakaan sekolah menyelenggarakan program pembelajaran yang memungkinkan para murid untuk memperoleh informasi secara efektif dan efisien. Di Amerika Serikat pustakawan di perpustakaan sekolah bersatu membentuk asosiasi dengan nama American Association of School Library (AASL).

Perpustakaan Akademik, mencakup Perpustakaan Perguruan Tinggi, Perpustakaan Riset, Perpustakaan, dan pembelajaran jarak jauh. Perpustakaan Akademik/Perpustakaan Perguruan Tinggi bekerja bersama-sama dengan anggota dari komunitas institusi mereka untuk berpartisipasi, mendukung, serta mencapai visi organisasi institusi dengan mengajarkan kompetensi inti dari literasi informasi. Di dalamnya termasuk kemampuan untuk mengidentifikasi kebutuhan informasi, akses informasi, serta memanfaatkan informasi. Didukung oleh pemahaman terhadap peraturan, aspek sosial dan etika di dalam penggunaan informasi. Perpustakaan perguruan tinggi di Amerika Serikat membentuk asosiasi yang dinamakan dengan Association of College \& Research Libraries (ACRL) adapun untuk di Indonesia dinamakan dengan Forum Perpustakaan Perguruan Tinggi (FPPT; 2018). Bagi perguruan tinggi di bawah Kementerian Pendidikan Nasional dan Asosiasi Perpustakaan Perguruan Tinggi Islam (APPTI), yang berada di bawah Kementerian Agama (APPTIS; 2018).

Berbagai jenis perpustakaan di atas berada di bawah pembinaan Perpustakaan Nasional hal ini 
dijelaskan dalam Undang-undang Nomor 43 Tahun 2007 Pasal 21 yang menyatakan bahwa, Perpustakaan Nasional bertugas:

1. Menetapkan kebijakan nasional, kebijakan umum, dan kebijakan teknis pengelolaan perpustakaan;

2. Melaksanakan pembinaan, pengembangan, evaluasi, dan koordinasi terhadap pengelolaan perpustakaan;

3. Membina kerja sama dalam pengelolaan berbagai jenis perpustakaan; dan

4. Mengembangkan standar nasional perpustakaan.

Selain tugas sebagaimana dimaksud pada ayat

1, Perpustakaan Nasional bertanggung jawab:

1. Mengembangkan koleksi nasional yang memfasilitasi terwujudnya masyarakat pembelajar sepanjang hayat;

2. Mengembangkan koleksi nasional untuk melestarikan hasil budaya bangsa;

3. Melakukan promosi perpustakaan dan gemar membaca dalam rangka mewujudkan masyarakat pembelajar sepanjang hayat; dan

4. Mengidentifikasi dan mengupayakan pengembalian naskah kuno yang berada di luar negeri.

Secara umum disebutkan di dalam Undangundang Nomor 43 Tahun 2007 tentang Perpustakaan menyatakan bahwa keberadaan perpustakaan tidak dapat dipisahkan dari peradaban dan budaya umat manusia. Tinggi rendahnya peradaban dan budaya suatu bangsa dapat dilihat dari kondisi perpustakaan yang dimiliki. Perpustakaan sebagai sistem pengelolaan rekaman gagasan, pemikiran, pengalaman, dan pengetahuan umat manusia, mempunyai fungsi utama melestarikan hasil budaya umat manusia tersebut, khususnya yang berbentuk dokumen karya cetak dan karya rekam lainnya, serta menyampaikan gagasan, pemikiran, pengalaman, dan pengetahuan umat manusia itu kepada generasigenerasi selanjutnya. Sasaran dari pelaksanaan fungsi ini adalah terbentuknya masyarakat yang mempunyai budaya membaca dan belajar sepanjang hayat. Perpustakaan berfungsi untuk mendukung Sistem Pendidikan Nasional sebagaimana diatur dengan Undang-Undang Nomor 20 Tahun 2003 tentang Sistem Pendidikan Nasional. Perpustakaan merupakan pusat sumber informasi, ilmu pengetahuan, teknologi, kesenian, dan kebudayaan. Selain itu, perpustakaan sebagai bagian dari masyarakat dunia ikut serta membangun masyarakat informasi berbasis teknologi informasi dan komunikasi sebagaimana dituangkan dalam Deklarasi World Summit of Information Society-WSIS, 12 Desember 2003.

\section{Pustakawan}

Undang-undang Nomor 43 Tahun 2007 Tentang Perpustakaan, Pustakawan adalah seseorang yang memiliki kompetensi yang diperoleh melalui pendidikan dan/atau pelatihan kepustakawanan serta mempunyai tugas dan tanggung jawab untuk melaksanakan pengelolaan dan pelayanan perpustakaan.

Menurut Your Dictionary (2018), definisi dari pustakawan ada dua yang pertama adalah a person in charge of a library dan yang kedua adalah a library worker trained in library science. Maka dapat disimpulkan bahwa, pustakawan adalah seseorang yang memiliki kompetensi dan bekerja di perpustakaan, dan bertugas serta bertanggung jawab untuk melaksanakan pengelolaan dan pelayanan perpustakaan.

Di Indonesia pustakawan dibedakan menjadi dua yaitu yang pertama adalah Pustakawan Pegawai Negeri Sipil (PNS) dan Pustakawan Non PNS. Sehubungan dengan tugas pengelolaan dan pelayanan khususnya bagi Pustakawan PNS disebut dengan Pejabat Fungsional Pustakawan. Adapun tugas pengelolaan tersebut meliputi perencanaan, dan monitoring serta evaluasi penyelenggaraan kegiatan perpustakaan. Selanjutnya kegiatan pelayanan perpustakaan meliputi pelayanan teknis dan pelayanan pemustaka (KepMenPAN RB Nomor 9 Tahun 2014).

Dalam rangka menjalankan tugas kepustakawanan maka diperlukan kompetensi dari para pustakawan. Kompetensi inti pustakawan menurut American Library Association (ALA) adalah pengetahuan yang dimiliki oleh pustakawan yang berhasil lulus Pasca Sarjana dari Jurusan IImu Perpustakaan Perguruan Tinggi yang diakreditasi oleh ALA. Di Indonesia kompetensi pustakawan diatur di dalam SKKNI (Standar Kompetensi Kerja Nasional Indonesia) Bidang Perpustakaan. Kompetensi Pustakawan terbagi kedalam tiga kelompok kompetensi, yaitu kompetensi dasar atau umum, kompetensi inti dan kompetensi khusus. Tujuan penyusunan SKKNI Bidang Perpustakaan adalah:

1. Meningkatkan profesionalisme pustakawan dalam menjalankan perannya sebagai mediator dan fasilitator informasi.

2. Menjadi tolak ukur kinerja pustakawan.

3. Menghasilkan pengelompokan keahlian pustakawan sesuai dengan standardisasi yang telah divalidasi oleh lembaga sertifikasi.

4. Memberi arah, petunjuk dan metode atau prosedur yang baku dalam menjalankan profesinya dengan mengedepankan kode etik kepustakawanan. 


\section{Penelitian Terdahulu}

Menurut Rasul and Sigh (2010) dalam penelitian terhadap peran Perpustakaan di Universitas, menunjukkan bahwa faktor penting dalam proses penelitian adalah aksesibilitas sumber daya informasi dan layanan yang disediakan oleh perpustakaan, dan mahasiswa adalah produsen utama penelitian di Universitas. Data dikumpulkan dari 375 mahasiswa pascasarjana yang dipilih secara acak di empat universitas negeri Malaysia. Temuan menunjukkan bahwa sebanyak $(90,1 \%)$ responden mengakui peran penting perpustakaan dalam memfasilitasi penelitian, dan $72,5 \%$ responden puas dengan peran saat ini yang dimainkan oleh perpustakaan.

Menurut Hart, G and Kleinveldt L (2011), melalui survei kuesioner terhadap 102 staf akademik di Cape Peninsula University of Technology, penelitian ini ingin mengetahui bagaimana para peneliti menggunakan perpustakaan lembaga mereka dalam penelitian mereka dan apa harapan mereka. Hasil penelitian menunjukkan bahwa 102 responden bahwa secara keseluruhan, sebagian besar (lebih dari 65\%) terus bergantung pada perpustakaan untuk akses ke sumber daya cetak dan elektronik. Responden menyatakan bahwa mereka sangat memerlukan informasi terbaru di bidangnya sebagai bahan penelitian, namun kompetensi pustakawannya masih kurang. Ditemukan juga bahwa sedikit dari peneliti yang berpartisipasi dalam pelatihan basis data, padahal sebagian besar peneliti mengakui bahwa peran basis data milik perpustakaan memberikan kontribusi yang sangat besar dalam penelitian mereka.

Hasil penelitian dari Hart, G; Kleinveldt L. (2011) menunjukkan bahwa peran perpustakaan di Universitas sangat penting dalam membantu penelitian yang dilakukan di universitas dengan berbagai cara antara Iain menyediakan literatur yang berkualitas, melakukan konsorsium dengan berbagai perpustakaan untuk meningkatkan akses sumber informasi yang beragam, dan di samping itu perpustakaan juga membangun situs interaktif supaya dapat diakses dimanapun dan kapanpun pemustaka berada. Perpustakaan juga membangun repository digital untuk mengelola pengetahuan yang dihasilkan oleh perguruan tinggi tersebut. Membangun subject gateway untuk mendapatkan akses ke situs lainnya dengan sangat cepat.

Penelitian dari Leslie J. Foutch (2016), menyatakan bahwa kolaborasi antara pustakawan dan peneliti dalam sebuah penelitian perlu dilakukan karena hal tersebut dapat membantu untuk meningkatkan kualitas penelitian dan pustakawan itu sendiri. Di dalam evolusi baru peranan pustakawan perguruan tinggi/akademik telah bergeser dengan berpartisipasi dalam siklus penelitian, pengajaran dan proses belajar.

Wilders, C. (2017) mengatakan bahwa Perpustakaan universitas mempertanyakan nilai tambah rak terbuka dengan buku. Karena publikasi ilmiah semakin tersedia dalam format elektronik, peran apa yang dimiliki rak buku di ruang perpustakaan masa depan? Studi kasus Perpustakaan Universitas Utrecht mengundang pustakawan untuk memikirkan kembali secara fundamental bagaimana mereka dapat memperkuat fungsi rak terbuka di perpustakaan mereka. Berdasarkan data akuisisi dan pengguna, dan pada wawancara dengan penerbit dan pengguna, artikel ini menunjukkan bahwa pada tahun 2025 rak buku dapat memainkan peran penting dalam menyediakan akses ke publikasi yang lebih disukai oleh pengguna dalam format kertas. Namun, rak buku seharusnya tidak lagi hanya berfokus pada publikasi kertas, tetapi juga publikasi digital, karena sebagian besar koleksi perpustakaan semakin menjadi hybrid. Selain itu, perpustakaan juga harus memikirkan cara untuk meningkatkan peran inspiratif dari rak buku. Kemudian, rak terbuka dapat memiliki nilai tambah dalam ruang perpustakaan di masa depan, menyediakan akses ke koleksi hybrid dan tempat yang menginspirasi untuk belajar.

Penelitian Andersona, C. and Phama, J. (2013) mengungkapkan bahwa akan terjadi penghematan ruangan bila dari Australian Academic Library buku tercetak diganti dengan buku elektronik. Hal ini disebabkan adanya duplikasi judul buku dengan ratarata 1,8 item per judul, penghematan ruang bisa sekitar $26 \%$. Di samping itu diketahui juga bahwa keuntungan dari buku elektronik adalah tidak bisa dipinjam, tidak bisa hilang, tidak bisa dicuri, tidak bisa dimutilasi dan tidak memakan ruang. Tidak dipungkiri juga bahwa buku tercetak terutama yang memiliki karakteristik desain yang berwarna-warni masih dipertahankan di universitas tersebut.

\section{METODE PENELITIAN}

Metode penelitian dilakukan dengan metoda Kualitatif dengan Metode Depth-Interview, yang dilakukan terhadap 4 orang masing - masing satker dilingkungan kedeputian IPSK, BMR (Balai Media Reproduksi) dan Pusat Penelitian Oseanografi. Hasil wawancara melalui dept interview tersebut direkam, dicatat, untuk selanjutnya dibuat tabel reduksi dari hasil - hasil wawancara yang sama. Selanjutnya hasil reduksi dibuat kesimpulan 
Tabel 1. Susunan responden yang diwawancara

\begin{tabular}{|l|l|}
\hline Kepala P2 Ekonomi +3 orang peneliti & Kawasan Jakarta \\
\hline Kepala P2 Politik +4 orang peneliti & Kawasan Jakarta \\
\hline Kepala P2 Kemasyarakatan dan Kebudayaan +3 orang peneliti & Kawasan Jakarta \\
\hline Kepala P2 Kewilayahan +3 orang peneliti & Kawasan Jakarta \\
\hline Kepala P2 Kependudukan + 4 orang peneliti & Kawasan Jakarta \\
\hline Kepala UPT Balai Media Reproduksi & Kawasan Jakarta \\
\hline Kepala P2 Oseanografi + 2 orang peneliti & Kawasan Jakarta \\
\hline $\begin{array}{l}\text { Kepala P2 Kebijakan dan Manajemen Iptek dan Inovasi }+2 \text { orang } \\
\text { peneliti }\end{array}$ & Kawasan Jakarta \\
\hline
\end{tabular}

\section{HASIL DAN PEMBAHASAN}

Hasil dari wawancara untuk responden di Lingkungan Jakarta dapat dilihat pada Lampiran 1, setelah dilakukan reduksi data, hasilnya dapat dirangkum sebagai berikut:

Berdasarkan pertanyaan apa yang dimaksud dengan perpustakaan, responden menjawab bahwa perpustakaan adalah pusat sumber informasi, yang tersedia dalam bentuk tercetak maupun dalam bentuk digital dan dapat digunakan sebagai bahan referensi penelitian. Selanjutnya dikatakan bahwa perpustakaan merupakan tempat dimana orang bisa mengakses buku, jurnal dan dokumen lainnya. Hal ini sesuai dengan definisi yang tercantum dalam Undang undang Nomor 43 Tahun 2007 Tentang Perpustakaan, yang dimaksud dengan perpustakaan adalah institusi pengelola koleksi karya tulis, karya cetak, dan/atau karya rekam secara profesional dengan sistem yang baku guna memenuhi kebutuhan pendidikan, penelitian, pelestarian, informasi, dan rekreasi para pemustaka.

Jawaban yang diberikan responden, terhadap pertanyaan apakah di LIPI masih membutuhkan perpustakaan, mereka semua mengatakan perpustakaan masih dibutuhkan, karena dapat membantu peneliti, karena tidak semua buku cetak sudah dikonversi dalam bentuk digital, terutama teori - teori .

Perpustakaan bidang ilmu sosial masih dibutuhkan oleh peneliti IPSK. Seperti diketahui kedeputian IPSK terdiri dari: Pusat Penelitian Kemasyarakatan dan Kebudayaan, Pusat Penelitian Kependudukan, Pusat Penelitian Politik, Pusat Penelitian Ekonomi, Pusat Penelitian Kependudukan dan Pusat Penelitian Sumber Daya Regional

Berdasarkan pertanyaan apakah yang dimaksud dengan pustakawan? peneliti mengatakan pustakawan adalah orang yang mempunyai keahlian untuk mengelola perpustakaan dan memberikan layanan kepada pengunjung perpustakaan dan pustakawan adalah mitra kerja peneliti dalam membantu penelitian.. Seperti yang dikatakan oleh Nitecki, D.A and Davis, MEK (2019) dalam Rahayu dan Royani 2019, bahwa pustakawan bisa terlibat dalam siklus penelitian yang mencakup sharing secara interaktif dan penggunaan kembali data, serta mengelola data penelitian (Research Data Management).

Untuk pertanyaan apakah di LIPI masih membutuhkan pustakawan? sebagian besar menjawab masih membutuhkan dan tidak bisa dihilangkan, karena tanpa pustakawan perpustakaan tidak dapat beroperasi.

Untuk pertanyaan apakah fungsi perpustakaan di LIPI? dijawab oleh sebagian besar peneliti bahwa perpustakaan adalah sebagai tempat yang menyediakan layanan informasi bagi peneliti; sebagai tempat yang menyediakan dan menyimpan buku yang dijadikan sumber informasi dalam referensi penelitian dan sebagai tempat diskusi dalam penelitian. Hal sesuai dengan definisi yang tertera dalam Kamus Webster yang dimaksud dengan perpustakaan adalah a place in which literary, musical, artistic, or reference materials (such as books, manuscripts, recordings, or films) are kept for use but not for sale (Webster; 1828). Berikutnya menurut Kamus Cambridge (Cambridge Dictionary) a building, room, or organization that has a collection, especially of books, for people to read or borrow, usually without payment; dapat juga diartikan sebagai a collection or set of books or other things, all produced in the same style or about the same subject.

Pertanyaan tentang apa fungsi pustakawan di LIPI, sebagian besar peneliti menjawab bahwa fungsi pustakawan adalah sebagai orang yang menata dan memelihara buku di perpustakaan, membantu peneliti dalam menelusur informasi yang dibutuhkan dan sebagai rekan diskusi tentang penelitian. Hal ini sesuai apa Schwartz, L.M., Lobst, B (2008) dalam Rahayu dan Royani 2019, bahwa pustakawan berperan dalam penelitian khususnya sebagai konsultan, penyedia konten, sekaligus sebagai peneliti. 
Pertanyaan tentang apa manfaat dari adanya perpustakaan di LIPI? Peneliti mengatakan bahwa manfaat perpustakaan adalah sebagai tempat untuk mencari informasi dan sebagai tempat yang menyediakan akses online, seperti jurnal online.

Mengenai manfaat adanya pustakawan adalah untuk membantu peneliti dalam memberikan pelayanan informasi yang dibutuhkan. Hal ini serupa dengan pertanyaan apakah fungsi pustakawan. Cave, A.J. dan Atkinson, L.(2017), mengatakan bahwa pustakawan berperan dalam penelitian.

Kendala apa saja yang dirasakan peneliti ketika berkunjung ke perpustakaan di LIPI? Menurut responden kendala yang dijumpai adalah: sulitnya mencari informasi yang dibutuhkan, tidak adanya petugas yang membantu ketika dibutuhkan dalam mencari informasi juga lokasinya kurang strategis dan situasinya kurang nyaman.

Kendala yang dirasakan bila berinteraksi dengan pustakawan di LIPI, adalah pustakawannya kurang optimal dalam memberikan pelayanan, kurangnya jumlah pustakawan untuk melayani pengunjung perpustakaan.

Harapan terhadap keberadaan perpustakaan adalah agar koleksi perpustakaannya dapat diakses dari mana saja, perlunya peningkatan fasilitas perpustakaan, agar lebih nyaman saat berkunjung, agar meningkatkan dan memperkaya koleksi yang ada di perpustakaan, menjadi perpustakaan induk yang berbasis digital.

Pustakawan diharapkan meningkatkan kompetensinya agar dapat memberikan pelayanan yang memuaskan, mereka diharapkan menjadi kolega yang baik dengan peneliti untuk memudahkan penelitian, pustakawan diharapkan mengubah mindet dan memiliki visi misi untuk membawa perpustakaan ke era digital.

\section{KESIMPULAN/REKOMENDASI}

Berdasarkan hasil dan pembahasan di atas perpustakaan di lingkungan LIPI Jakarta tetap berlanjut baik dalam bentuk konvensional maupun digital karena fungsi dan manfaat yang diberikan kepada peneliti dan civitas LIPI pada umumnya. Perpustakaan tetap diperlukan, karena informasi yang ada pada perpustakaan tersebut merupakan harta kekayaan intelektual yang harus dipelihara dan dilestarikan agar bisa diwariskan untuk generasi mendatang serta dikembangkan agar didapat kekayaan intelektual yang baru. Perpustakaan dilingkungan LIPI dituntut untuk memberikan kenyamanan bagi pemustaka. Pustakawan harus meningkatkan kompetensinya sehingga dapat memberikan layanan yang prima pemustaka.

\section{DAFTAR PUSTAKA}

Andersona, C. and Phama, J. (2013). Practical overlap: The possibility of replacing print books with ebooks. Australian Academic \& Research Libraries, 2013 Vol. 44, No. 1, 40-49, http://dx.doi.org/ 10.1080/00048623.2013.773866

Asosiasi Perpustakaan Perguruan Tinggi Islam S. (2018). Diakses dari: https://apptis.or.id/, 13 Februari 2019.

Barbara DiCicco Bloom; Crabtree, Benjamin F. (2006). The qualitative research interview. 40 (4): $314-321$.

Cambride Dictionary. (2019). Diakses dari https:// dictionary.cambridge.org/; pada 13 Februari 2019.

Cambridge Advanced Learner's Dictionary \& Thesaurus (C) Cambridge University Press. Diakses dari : https://dictionary.cambridge.org/dictionary/ english/librarian, pada 14 Februari 2019.

Chicago: ALA. (2010). George Eberhart. Definition of a Library: General Definition. Diakses dari https:/ /libguides.ala.org/library-definition, 13 Februari 2019.

Conducting an interview. Diakses dari: ttps:// www2.open.ac.uk/students/skillsforstudy/conducting-an-interview.php, diakses 14 Februari 2019

Pusbindiklat LIPI. (2018, Februari). Data Statistik Peneliti Per Januari 2018. Diperoleh 12 Februari 2019, dari http://pusbindiklat.lipi.go.id/id/ pembinaan-peneliti/data-peneliti/.

Forum Perpustakaan Perguruan Tinggi. (2018). Diakses dari: https://fppti-dkijakarta.or.id, pada 13 Februari 2019.

Hart, G. Kleinveldt, L. (2011) The role of an academic library in research: Researchers' perspectives at a South African University of Technology. South African Journal of Libraries and Information Science; SA Jnl Libs \& Info Sci 2011, 77(1)

Jamshed S. (2014). Qualitative research method-interviewing and observation. Journal of basic and clinical phrmacy, 5(4), 87-8. 
KepMenPAN RB Nomor 9 Tahun 2014. (2014). Tentang Penetapan Rancangan Standar Kompetensi Kerja Nasional Indonesia Sektor Jasa Kemasyarakatan, Sosial Budaya, Hiburan dan Perorangan Lainnya Bidang Perpustakaan menjadi Standar Kompetensi Kerja Nasional Indonesia.

Kvale S. (1996). InterViews: An Introduction to Qualitative Research Interviews, Sage Publications, California. Diakses dari: https://www2.open.ac.uk/ students/skillsforstudy/conducting-aninterview.php

Leslie J. Foutch (2016) A New Partner in the Process: The Role of a Librarian on a Faculty Research Team. Collaborative Librarianship 8(2):8083 (2016).

Library, Definition of Library by Merriam-Webster. Diakses dari https://www.merriam-webster.com/ dictionary/library diakses 13 Februari 2019.

Matthew B. Miles, A. Michael Huberman, Johnny Saldaña, (2014). Qualitative data analysis: a methods sourcebook / Arizona State University. Third edition.

McNamara, Carter. (1999). General Guidelines for Conducting Interviews, Minnesota.
Rasul, A; and Singh, D. (2010). The role of academic libraries in facilitating postgraduate students' research. Malaysian Journal of Library \& Information Science 15 (3): $75-84$.

Undang-Undang Republik Indonesia Nomor 43 Tahun 2007 Tentang Perpustakaan

Wilders, C. (2017). Predicting the Role of Library Bookshelves in 2025. The Journal of Academic Librarianship 3: 384-391

Rahayu, Rochani Nani dan Royani, Yupi (2019) Peran Pustakawan Sebagai Mitra Riset di Era Digital: Sebuah Literature Review. Prosiding Seminar Nasional UPT Perpustakaan Universitas Jember 2019

Schwartz, L.M., Lobst, B (2008) dalam Rahayu dan Royani (2019) Peran Pustakawan Sebagai Mitra Riset di Era Digital: Sebuah Literature Review. Prosiding Seminar Nasional UPT Perpustakaan Universitas Jember 2019

Cave, A.J. dan Atkinson, L.L. (2017), Every home should have one: The critical role of research librarian. British Journal of General Practice 67 (657). pp.174 


\section{Lampiran 1. Jawaban Responden terhadap Pertanyaan}

Keterangan :

(L) Laki-laki

(P) Perempuan

1. P2K

Informan : HY (L), T (L), As (P), D (P), BS (L)

2. P2P

Informan : FN (L), AR (L), Sa (P), Al (P), T (L)

3. P2O

Informan : Aan (L), Rd (L), HT (L)

4. BMR

Informan : Rh $(P)$

5. PMB

Informan : SSP $(P)$, WMS $(P)$, NW $(P)$, AW $(P)$

6. PSDR

Informan : GW $(P), M K(L), M P(P), E T(P)$

7. P2E

Informan : $A E(L), T E(P)$, IS (L), S (L)

8. Papiptek

Informan : RF (L), SM (L), LA (P) 


\begin{tabular}{|c|c|c|c|}
\hline No. & Responden & Pertanyaan & Jawaban \\
\hline \multirow{29}{*}{1.} & HY (L) P2K & \multirow{29}{*}{$\begin{array}{c}\text { Apa yang } \\
\text { dimaksud dengan } \\
\text { perpustakaan }\end{array}$} & Tempat membaca dan mencari informasi \\
\hline & $\mathrm{T}(\mathrm{L}) \mathrm{P} 2 \mathrm{~K}$ & & Perpustakaan tempat penyedia informasi \\
\hline & As (P) P2K & & Perpustakaan untuk mendukung aktivitas akademik \\
\hline & $\mathrm{D}(\mathrm{P}) \mathrm{P} 2 \mathrm{~K}$ & & Perpustakaan tempat menyimpan koleksi \\
\hline & $\mathrm{BS}(\mathrm{L}) \mathrm{P} 2 \mathrm{~K}$ & & Perpustakaan sebagai pusat informasi \\
\hline & FN (L) P2P & & Sumber informasi untuk kegiatan penelitian \\
\hline & AR (L) P2P & & $\begin{array}{l}\text { Tempat menyimpan dokumen-dokumen lama dan } \\
\text { baru }\end{array}$ \\
\hline & Sa (P) P2P & & Pusat informasi para peneliti \\
\hline & $\mathrm{Al}(\mathrm{P}) \mathrm{P} 2 \mathrm{P}$ & & Tempat menyimpan koleksi \\
\hline & $\mathrm{T}(\mathrm{L}) \mathrm{P} 2 \mathrm{P}$ & & Tempat koleksi jurnal dan buku \\
\hline & Aan (L) P2O & & Tempat menyimpan laporan hasil penelitian \\
\hline & $\mathrm{Rd}(\mathrm{L}) \mathrm{P} 2 \mathrm{O}$ & & Tempat mencari informasi lama dan terbarukan \\
\hline & HT (L) P2O & & Tempat koleksi data-data yang diperlukan \\
\hline & Rh (P) BMR & & Sumber informasi dan penyedia koleksi \\
\hline & SSP (P) PMB & & $\begin{array}{l}\text { Perpustakaan adalah sumber } \\
\text { informasi.Perpustakaan adalah akses Informasi } \\
\text { ilmiah yang bisa memberikan tambahan kepada } \\
\text { bahan keilmuan yang sedang dikerjakan. }\end{array}$ \\
\hline & WMS (P) PMB & & $\begin{array}{l}\text { Perpustakaan tempat ruang berkumpul dan diskusi, } \\
\text { perpustakaan adalah sumber yang bisa membantu } \\
\text { peneliti memberikan keyword dari bahan-bahan yang } \\
\text { dicari }\end{array}$ \\
\hline & NW (P) PMB & & $\begin{array}{l}\text { Perpustakaan adalah sumber informasi, } \\
\text { perpustakaan bagi peneliti adalah sumber literatur, } \\
\text { jurnal, hasil penelitian, thesis, dan disertasi }\end{array}$ \\
\hline & AW (P) PMB & & Perpustakaan adalah sumber koleksi. \\
\hline & GW (P) PSDR & & $\begin{array}{l}\text { Perpustakaan menurut saya adalah tempat koleksi } \\
\text { buku, jurnal, dokumen, buku reference untuk pencari } \\
\text { selain itu juga bisa sebagai tempat belajar dan } \\
\text { rekreasi. }\end{array}$ \\
\hline & MK (L) PSDR & & Koleksi buku, laporan penelitian, jurnal. \\
\hline & MP (P) PSDR & & $\begin{array}{l}\text { Perpustakaan itu tempat kita mendapatkan banyak } \\
\text { hal, seperti buku, literatur, informasi berbagai bidang } \\
\text { baik secara digital ataupun konvensional }\end{array}$ \\
\hline & ET (P) PSDR & & $\begin{array}{l}\text { Perpustakaan adalah tempat koleksi buku, tempat } \\
\text { dokumentasi, dan tempat mendapatkan informasi }\end{array}$ \\
\hline & AE (L) P2E & & $\begin{array}{l}\text { Perpustakaan dalam konteks ilmu sosial adalah } \\
\text { sumber utama sebelum kita melakukan riset. }\end{array}$ \\
\hline & TE (P) P2E & & $\begin{array}{l}\text { Perpustakaan adalah tempat dimana orang bisa } \\
\text { mengakses buku, jurnal, atau informasi data dan } \\
\text { sebagainya. }\end{array}$ \\
\hline & JS (L) P2E & & $\begin{array}{l}\text { Tempat kita mencari data, sumber-sumber informasi, } \\
\text { tempat untuk sharing, dan diskusi, dengan satu tim. }\end{array}$ \\
\hline & S (L) P2E & & $\begin{array}{l}\text { Perpustakaan adalah tempat atau fasilitas untuk } \\
\text { menyediakan informasi mulai dari informasi yang } \\
\text { hardkopi maupun digital. }\end{array}$ \\
\hline & RF (L) Papiptek & & $\begin{array}{l}\text { Pusat dokumentasi data-data, informasi ilmu } \\
\text { pengetahuan yang dibuat dalam format buku, } \\
\text { majalah laporan, dan jurnal. }\end{array}$ \\
\hline & SM (L) Papiptek & & $\begin{array}{l}\text { Perpustakaan itu adalah center of knowledge, } \\
\text { pusatnya ilmu pengetahuan. }\end{array}$ \\
\hline & LA (P) Papiptek & & - \\
\hline
\end{tabular}




\begin{tabular}{|c|c|c|c|}
\hline No. & Responden & Pertanyaan & Jawaban \\
\hline \multirow{29}{*}{2.} & HY (L) P2K & \multirow{29}{*}{$\begin{array}{c}\text { Apakah di LIPI } \\
\text { masih } \\
\text { membutuhkan } \\
\text { perpustakaan }\end{array}$} & Masih membutuhkan karena sangat membantu \\
\hline & $\mathrm{T}(\mathrm{L}) \mathrm{P} 2 \mathrm{~K}$ & & Sangat diperlukan \\
\hline & As $(\mathrm{P}) \mathrm{P} 2 \mathrm{~K}$ & & Tetap perlu \\
\hline & $\mathrm{D}(\mathrm{P}) \mathrm{P} 2 \mathrm{~K}$ & & Masih \\
\hline & BS (L) P2K & & Masih \\
\hline & FN (L) P2P & & Masih \\
\hline & AR (L) P2P & & Masih \\
\hline & $\mathrm{Sa}(\mathrm{P}) \mathrm{P} 2 \mathrm{P}$ & & Masih \\
\hline & $\mathrm{Al}(\mathrm{P}) \mathrm{P} 2 \mathrm{P}$ & & Masih \\
\hline & $\mathrm{T}(\mathrm{L}) \mathrm{P} 2 \mathrm{P}$ & & Masih \\
\hline & Aan (L) P2O & & Masih \\
\hline & $\mathrm{Rd}(\mathrm{L}) \mathrm{P} 2 \mathrm{O}$ & & Masih perlu \\
\hline & HT (L) P2O & & Masih butuh \\
\hline & Rh $(\mathrm{P}) \mathrm{BMR}$ & & Masih \\
\hline & SSP (P) PMB & & Penting dan masih dibutuhkan \\
\hline & WMS (P) PMB & & $\begin{array}{l}\text { lya karena sebuah konsekuensi logis dari } \\
\text { Lembaga penelitian bahwa harus mempunyai } \\
\text { perpustakaan. }\end{array}$ \\
\hline & NW (P) PMB & & $\begin{array}{l}\text { Dibutuhkan karena perpustakaan mempunyai } \\
\text { keterkaitan dengan peneliti }\end{array}$ \\
\hline & AW (P) PMB & & Butuh dan perlu \\
\hline & GW (P) PSDR & & Masih membutuhkan \\
\hline & MK (L) PSDR & & Masih \\
\hline & MP (P) PSDR & & lya. \\
\hline & ET (P) PSDR & & Butuh \\
\hline & $\mathrm{AE}(\mathrm{L}) \mathrm{P} 2 \mathrm{E}$ & & Masih \\
\hline & TE (P) P2E & & Masih butuh \\
\hline & IS (L) P2E & & Penting \\
\hline & S (L) P2E & & $\begin{array}{l}\text { Masih dibutuhkan apalagi untuk kegiatan } \\
\text { penelitian. }\end{array}$ \\
\hline & RF (L) Papiptek & & lya pasti \\
\hline & SM (L) Papiptek & & Butuh \\
\hline & LA (P) Papiptek & & - \\
\hline
\end{tabular}




\begin{tabular}{|c|c|c|c|}
\hline No. & Responden & Pertanyaan & Jawaban \\
\hline \multirow{29}{*}{3.} & HY (L) P2K & \multirow{28}{*}{$\begin{array}{l}\text { Apa yang dimaksud } \\
\text { dengan pustakawan }\end{array}$} & - \\
\hline & $\mathrm{T}(\mathrm{L}) \mathrm{P} 2 \mathrm{~K}$ & & - \\
\hline & As $(\mathrm{P}) \mathrm{P} 2 \mathrm{~K}$ & & Orang yang meringankan pekerjaa peneliti \\
\hline & $\mathrm{D}(\mathrm{P}) \mathrm{P} 2 \mathrm{~K}$ & & $\begin{array}{l}\text { Orang yang melayani pengunjung dan menguasai } \\
\text { tata letak buku }\end{array}$ \\
\hline & BS (L) P2K & & Orang yang mengelola perpustakaan \\
\hline & FN (L) P2P & & Orang yang membantu di perpustakaan \\
\hline & AR (L) P2P & & Orang yang menggarap informasi di perpustakaan \\
\hline & Sa (P) P2P & & Orang yang menjadi narahubung di perpustakaan \\
\hline & $\mathrm{Al}(\mathrm{P}) \mathrm{P} 2 \mathrm{P}$ & & Orang yang membantu pengunjung mencari bahan \\
\hline & $\mathrm{T}(\mathrm{L}) \mathrm{P} 2 \mathrm{P}$ & & $\begin{array}{l}\text { Orang yang membantu keberjalanan aktivitas di } \\
\text { perpustakaan }\end{array}$ \\
\hline & Aan (L) P2O & & Orang yang membantu pekerjaan di perpustakaan \\
\hline & $\mathrm{Rd}(\mathrm{L}) \mathrm{P} 2 \mathrm{O}$ & & $\begin{array}{l}\text { Orang yang membantuk mencarikan kebutuhan } \\
\text { peneliti di perpustakaan }\end{array}$ \\
\hline & HT (L) P2O & & $\begin{array}{l}\text { Orang yang memahami cara mengelola } \\
\text { perpustakaan }\end{array}$ \\
\hline & Rh (P) BMR & & Orang yang mengelola buku-buku di perpustakaan \\
\hline & SSP (P) PMB & & $\begin{array}{l}\text { Pustakawan adalah mereka yang mempunyai ilmu } \\
\text { pada koleksi, dokumentasi, mengatur, } \\
\text { megorganisir, mengklarifikasi, sehingga jika } \\
\text { dibutuhkan mereka bisa memberikan pelayanan. }\end{array}$ \\
\hline & WMS (P) PMB & & $\begin{array}{l}\text { Pustakawan adalah orang yang ahli dalam } \\
\text { pengelolaan pengetahuan. Sehingga terkadang } \\
\text { pustakawan sendiri tidak menyadari kalau dirinya } \\
\text { penting. }\end{array}$ \\
\hline & NW (P) PMB & & Mitra kerja dalam penelitian \\
\hline & AW (P) PMB & & $\begin{array}{l}\text { Pustakawan adalah seseorang yang menguasai } \\
\text { koleksi perpustakaan dan mampu melayani serta } \\
\text { memenuhi kebutuhan peneliti }\end{array}$ \\
\hline & GW (P) PSDR & & $\begin{array}{l}\text { Pustakawan adalah orang yang bekerja sebagai } \\
\text { penataan koleksi, dan memberikan pelayanan }\end{array}$ \\
\hline & MK (L) PSDR & & $\begin{array}{l}\text { Pustakawan adalah orang yang bekerja di } \\
\text { perpustakaan. Kalau di LIPI pustakawan kaitannya } \\
\text { dengan fungsional. Staf perpustakaan adalah } \\
\text { pustakawan. }\end{array}$ \\
\hline & MP (P) PSDR & & $\begin{array}{l}\text { Pustakawan adalah orang yang membantu peneliti } \\
\text { mencarikan literatur dan mengelola perpustakaan }\end{array}$ \\
\hline & ET (P) PSDR & & $\begin{array}{l}\text { Pustakawan adalah sumber daya manusia yang } \\
\text { melakukan, memelihara, mengumpulkan, } \\
\text { mendiseminasi, dan yang mengetahui keberadaan } \\
\text { buku yang kita ketahui. }\end{array}$ \\
\hline & AE (L) P2E & & $\begin{array}{l}\text { Pustakawan itu yang menata, mengorganisir, dan } \\
\text { melayani user. }\end{array}$ \\
\hline & TE (P) P2E & & $\begin{array}{l}\text { Orang yang mengelola perpustakaan dan menata, } \\
\text { sehingga data yang diakses lebih mudah ditemukan }\end{array}$ \\
\hline & IS (L) P2E & & $\begin{array}{l}\text { Orang yang bertugas memberikan informasi dan } \\
\text { data, pustakawan tempat untuk bertanya. }\end{array}$ \\
\hline & S (L) P2E & & $\begin{array}{l}\text { Orang yang yang mempunyai tugas dan mengelola } \\
\text { perpustakaan. }\end{array}$ \\
\hline & RF (L) Papiptek & & $\begin{array}{l}\text { Orang yang mengelola dan memberikan pelayanan } \\
\text { kepada pengunjung perpustakaan. }\end{array}$ \\
\hline & SM (L) Papiptek & & $\begin{array}{l}\text { Pustakawan adalah orang yang dapat menelusur, } \\
\text { mengatur buku, dan memberikan rekomendasi } \\
\text { kepada peneliti. }\end{array}$ \\
\hline & LA (P) Papiptek & & - \\
\hline
\end{tabular}




\begin{tabular}{|c|c|c|c|}
\hline No. & Responden & Pertanyaan & Jawaban \\
\hline \multirow{29}{*}{4.} & $\mathrm{HY}(\mathrm{L}) \mathrm{P} 2 \mathrm{~K}$ & \multirow{29}{*}{$\begin{array}{l}\text { Apakah di LIPI } \\
\text { masih } \\
\text { membutuhkan } \\
\text { pustakawan }\end{array}$} & - \\
\hline & $\mathrm{T}(\mathrm{L}) \mathrm{P} 2 \mathrm{~K}$ & & - \\
\hline & As $(\mathrm{P}) \mathrm{P} 2 \mathrm{~K}$ & & - \\
\hline & $\mathrm{D}(\mathrm{P}) \mathrm{P} 2 \mathrm{~K}$ & & - \\
\hline & BS (L) P2K & & - \\
\hline & FN (L) P2P & & Masih untuk mengelola buku-buku \\
\hline & AR (L) P2P & & Masih \\
\hline & $\mathrm{Sa}(\mathrm{P}) \mathrm{P} 2 \mathrm{P}$ & & Masih \\
\hline & $\mathrm{Al}(\mathrm{P}) \mathrm{P} 2 \mathrm{P}$ & & Masih \\
\hline & $\mathrm{T}(\mathrm{L}) \mathrm{P} 2 \mathrm{P}$ & & Masih \\
\hline & Aan (L) P2O & & Masih \\
\hline & Rd (L) P2O & & Masih \\
\hline & $\mathrm{HT}(\mathrm{L}) \mathrm{P} 2 \mathrm{O}$ & & Masih \\
\hline & Rh $(\mathrm{P}) \mathrm{BMR}$ & & Masih \\
\hline & SSP (P) PMB & & Masih dan tidak bisa dihilangkan \\
\hline & WMS (P) PMB & & Butuh \\
\hline & NW (P) PMB & & Butuh \\
\hline & AW (P) PMB & & Perlu \\
\hline & GW (P) PSDR & & $\begin{array}{l}\text { Perlu, kalau perpustakaan masih perlu berarti } \\
\text { pustakawan juga masuh dibutuhkan. }\end{array}$ \\
\hline & MK (L) PSDR & & Masih. \\
\hline & MP (P) PSDR & & Masih \\
\hline & ET (P) PSDR & & Masih. \\
\hline & AE (L) P2E & & Masih. \\
\hline & TE (P) P2E & & Ya, sangat membutuhkan \\
\hline & IS (L) P2E & & $\begin{array}{l}\text { Penting karena perpustakaan tanpa pustakawan } \\
\text { tidak akan bisa beroperasi. }\end{array}$ \\
\hline & S (L) P2E & & Masih \\
\hline & RF (L) Papiptek & & lya pasti \\
\hline & SM (L) Papiptek & & Butuh \\
\hline & LA (P) Papiptek & & - \\
\hline
\end{tabular}




\begin{tabular}{|c|c|c|c|}
\hline No. & Responden & Pertanyaan & Jawaban \\
\hline \multirow{29}{*}{5.} & HY (L) P2K & \multirow{29}{*}{$\begin{array}{l}\text { Apakah fungsi } \\
\text { perpustakaan PDII } \\
\text { LIPI }\end{array}$} & 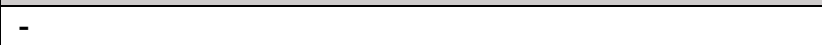 \\
\hline & $\mathrm{T}(\mathrm{L}) \mathrm{P} 2 \mathrm{~K}$ & & - \\
\hline & As $(\mathrm{P}) \mathrm{P} 2 \mathrm{~K}$ & & - \\
\hline & $\mathrm{D}(\mathrm{P}) \mathrm{P} 2 \mathrm{~K}$ & & - \\
\hline & $\mathrm{BS}(\mathrm{L}) \mathrm{P} 2 \mathrm{~K}$ & & - \\
\hline & FN (L) P2P & & Sama dengan perpustakaan pada umumnya \\
\hline & AR (L) P2P & & - \\
\hline & Sa (P) P2P & & - \\
\hline & $\mathrm{Al}(\mathrm{P}) \mathrm{P} 2 \mathrm{P}$ & & - \\
\hline & $\mathrm{T}(\mathrm{L}) \mathrm{P} 2 \mathrm{P}$ & & - \\
\hline & Aan (L) P2O & & - \\
\hline & $\mathrm{Rd}(\mathrm{L}) \mathrm{P} 2 \mathrm{O}$ & & - \\
\hline & HT (L) P2O & & - \\
\hline & Rh (P) BMR & & Penyedia koleksi \\
\hline & SSP (P) PMB & & $\begin{array}{l}\text { Sebagai tempat koleksi yang bisa memberikan } \\
\text { masukan dan pelayanan }\end{array}$ \\
\hline & WMS (P) PMB & & $\begin{array}{l}\text { Fungsi edukasi jangka panjang, rekreatif, informasi, } \\
\text { dan pengelolaan pengetahuan }\end{array}$ \\
\hline & NW (P) PMB & & Fungsi Informasi \\
\hline & AW (P) PMB & & Fungsi infomasi dan layanan konsultasi literatur \\
\hline & GW (P) PSDR & & - \\
\hline & MK (L) PSDR & & $\begin{array}{l}\text { Sebagai layanan informasi bagi para peneliti dan } \\
\text { mahasiswa }\end{array}$ \\
\hline & MP (P) PSDR & & - \\
\hline & ET (P) PSDR & & $\begin{array}{l}\text { Menyediakan buku yang aku butuhkan } \\
\text { penyimpanan Buku sebagai sumber utama } \\
\text { penelitian, fungsi rekreatif, mengajak anak piknik ke } \\
\text { perpustakaan. }\end{array}$ \\
\hline & $\mathrm{AE}(\mathrm{L}) \mathrm{P} 2 \mathrm{E}$ & & Fungsi perpustakaan LIPI itu seperti perpusnas. \\
\hline & TE (P) P2E & & Menjadi tempat kita untuk tahu hal-hal yang baru. \\
\hline & IS (L) P2E & & - \\
\hline & S (L) P2E & & $\begin{array}{l}\text { Menyediakan informasi yang dibutuhkan peneliti, } \\
\text { seperti jurnal-jurnal ilmiah, dan buku cetak serta } \\
\text { digital. }\end{array}$ \\
\hline & RF (L) Papiptek & & $\begin{array}{l}\text { Belum terlalu secara intens menggunakan jasa } \\
\text { PDII, melakukan diskusi dengan pustakawan di } \\
\text { sana mengenai melakukan penelitian. }\end{array}$ \\
\hline & $\begin{array}{l}\text { SM (L) } \\
\text { Papiptek }\end{array}$ & & - \\
\hline & LA (P) Papiptek & & - \\
\hline
\end{tabular}




\begin{tabular}{|c|c|c|c|}
\hline No. & Responden & Pertanyaan & Jawaban \\
\hline & HY (L) P2K & \multirow{29}{*}{$\begin{array}{l}\text { Apakah fungsi } \\
\text { pustakawan di LIPI }\end{array}$} & - \\
\hline & $\mathrm{T}(\mathrm{L}) \mathrm{P} 2 \mathrm{~K}$ & & - \\
\hline & As $(\mathrm{P}) \mathrm{P} 2 \mathrm{~K}$ & & - \\
\hline & $\mathrm{D}(\mathrm{P}) \mathrm{P} 2 \mathrm{~K}$ & & - \\
\hline & BS (L) P2K & & - \\
\hline & FN (L) P2P & & - \\
\hline & AR (L) P2P & & - \\
\hline & Sa $(P)$ P2P & & - \\
\hline & $\mathrm{Al}(\mathrm{P}) \mathrm{P} 2 \mathrm{P}$ & & - \\
\hline & $\mathrm{T}(\mathrm{L}) \mathrm{P} 2 \mathrm{P}$ & & - \\
\hline & Aan (L) P2O & & - \\
\hline & $\mathrm{Rd}(\mathrm{L}) \mathrm{P} 2 \mathrm{O}$ & & - \\
\hline & HT (L) P2O & & - \\
\hline & Rh (P) BMR & & - \\
\hline & SSP (P) PMB & & $\begin{array}{l}\text { Pustakawan adalah orang yang berfungi sebagai } \\
\text { penelusur informasi, seperti data dan koleksi }\end{array}$ \\
\hline & WMS (P) PMB & & Mengelola pengetahuan dan menelusur literatur. \\
\hline & NW (P) PMB & & - \\
\hline & AW (P) PMB & & - \\
\hline & GW (P) PSDR & & $\begin{array}{l}\text { Pustakawan berfungsi untuk penataan koleksi dan } \\
\text { memberikan pelayanan. }\end{array}$ \\
\hline & MK (L) PSDR & & Memberikan bantuan kepada peneliti \\
\hline & MP (P) PSDR & & Memberikan penelusuran Info \\
\hline & ET (P) PSDR & & $\begin{array}{l}\text { Memelihara semua buku-buku, mendiseminasi } \\
\text { semua hasil penelitian, dan mencari literatur }\end{array}$ \\
\hline & $A E(L) P 2 E$ & & - \\
\hline & TE (P) P2E & & Fungsi layanan \\
\hline & IS (L) P2E & & Membantu peneliti mendapatkan informasi. \\
\hline & $S(L) P 2 E$ & & Penelusuran informasi \\
\hline & RF (L) Papiptek & & Sebagai rekan diskusi tentang penelitian. \\
\hline & $\begin{array}{l}\text { SM (L) } \\
\text { Papiptek }\end{array}$ & & - \\
\hline 6. & LA (P) Papiptek & & - \\
\hline
\end{tabular}




\begin{tabular}{|c|c|c|c|}
\hline No. & Responden & Pertanyaan & Jawaban \\
\hline \multirow{29}{*}{7.} & HY (L) P2K & \multirow{29}{*}{$\begin{array}{c}\text { Apa manfaat dari } \\
\text { adanya perpustakaan } \\
\text { di LIPI }\end{array}$} & 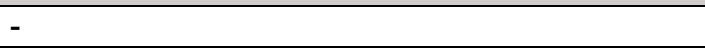 \\
\hline & $\mathrm{T}(\mathrm{L}) \mathrm{P} 2 \mathrm{~K}$ & & - \\
\hline & As $(\mathrm{P}) \mathrm{P} 2 \mathrm{~K}$ & & - \\
\hline & D (P) P2K & & - \\
\hline & BS (L) P2K & & - \\
\hline & FN (L) P2P & & - \\
\hline & AR (L) P2P & & - \\
\hline & Sa (P) P2P & & - \\
\hline & $\mathrm{Al}(\mathrm{P}) \mathrm{P} 2 \mathrm{P}$ & & - \\
\hline & $\mathrm{T}(\mathrm{L}) \mathrm{P} 2 \mathrm{P}$ & & - \\
\hline & Aan (L) P2O & & - \\
\hline & $\mathrm{Rd}(\mathrm{L}) \mathrm{P} 2 \mathrm{O}$ & & - \\
\hline & HT (L) P2O & & - \\
\hline & Rh (P) BMR & & - \\
\hline & SSP (P) PMB & & Sebagai pengadaan buku \\
\hline & WMS (P) PMB & & Sebagai tempat bekerja dan sumber literatur \\
\hline & NW (P) PMB & & Tempat kerja \\
\hline & AW (P) PMB & & $\begin{array}{l}\text { Sebagai tempat memanfaatkan akses online, } \\
\text { seperti jurnal online. }\end{array}$ \\
\hline & GW (P) PSDR & & - \\
\hline & MK (L) PSDR & & $\begin{array}{l}\text { Alternative bekerja selain di ruang kantor. } \\
\text { Membantu peneliti dengan literatur. }\end{array}$ \\
\hline & MP (P) PSDR & & - \\
\hline & ET (P) PSDR & & Mencari buku sebagai sumber utama \\
\hline & AE (L) P2E & & Sumber Informasi \\
\hline & TE (P) P2E & & Dapat meningkatkan apapun \\
\hline & IS (L) P2E & & - \\
\hline & S (L) P2E & & - \\
\hline & RF (L) Papiptek & & - \\
\hline & $\begin{array}{l}\text { SM (L) } \\
\text { Papiptek }\end{array}$ & & - \\
\hline & LA (P) Papiptek & & - \\
\hline
\end{tabular}




\begin{tabular}{|c|c|c|c|}
\hline No. & Responden & Pertanyaan & Jawaban \\
\hline \multirow{29}{*}{8.} & HY (L) P2K & \multirow{29}{*}{$\begin{array}{l}\text { Apa manfaat dari } \\
\text { adanya pustakawan }\end{array}$} & - \\
\hline & $\mathrm{T}(\mathrm{L}) \mathrm{P} 2 \mathrm{~K}$ & & - \\
\hline & As $(\mathrm{P}) \mathrm{P} 2 \mathrm{~K}$ & & - \\
\hline & $\mathrm{D}(\mathrm{P}) \mathrm{P} 2 \mathrm{~K}$ & & - \\
\hline & BS (L) P2K & & - \\
\hline & FN (L) P2P & & - \\
\hline & AR (L) P2P & & - \\
\hline & Sa $(P) P 2 P$ & & - \\
\hline & $\mathrm{Al}(\mathrm{P}) \mathrm{P} 2 \mathrm{P}$ & & - \\
\hline & $\mathrm{T}(\mathrm{L}) \mathrm{P} 2 \mathrm{P}$ & & - \\
\hline & Aan (L) P2O & & - \\
\hline & Rd (L) P2O & & - \\
\hline & HT (L) P2O & & - \\
\hline & Rh (P) BMR & & - \\
\hline & SSP (P) PMB & & - \\
\hline & WMS (P) PMB & & - \\
\hline & NW (P) PMB & & - \\
\hline & AW (P) PMB & & - \\
\hline & GW (P) PSDR & & - \\
\hline & MK (L) PSDR & & $\begin{array}{l}\text { Membantu peneliti dengan tinjauan literatur untuk } \\
\text { eksternal dan internal. }\end{array}$ \\
\hline & MP (P) PSDR & & Memberikan pelayanan informasi \\
\hline & ET (P) PSDR & & Literature review, preservasi pemeliharaan buku. \\
\hline & AE (L) P2E & & Penelusuran info \\
\hline & TE (P) P2E & & Penelusuran koleksi \\
\hline & IS (L) P2E & & Penelusuran informasi \\
\hline & S (L) P2E & & - \\
\hline & RF (L) Papiptek & & - \\
\hline & $\begin{array}{l}\text { SM (L) } \\
\text { Papiptek }\end{array}$ & & - \\
\hline & LA (P) Papiptek & & - \\
\hline
\end{tabular}




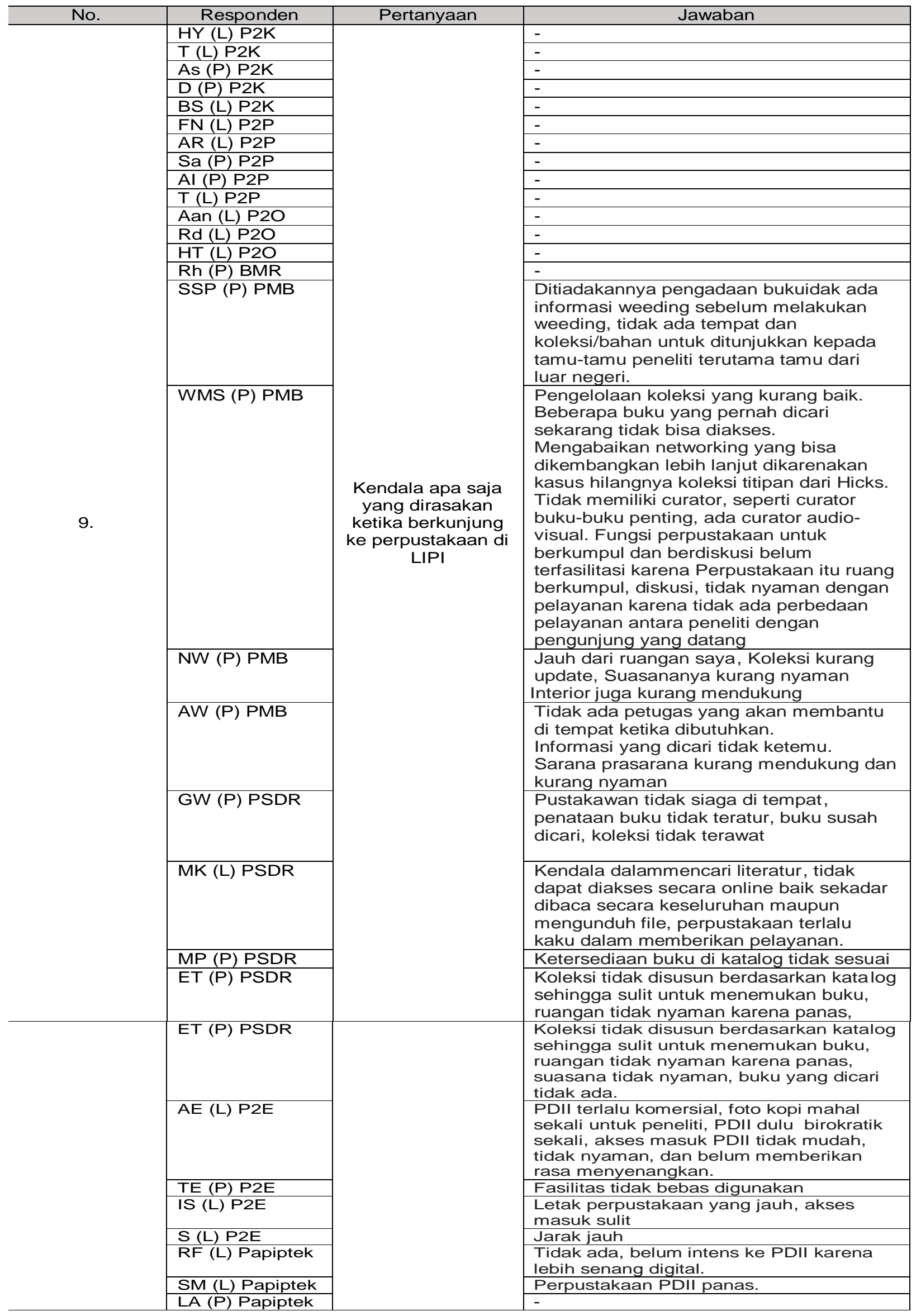




\begin{tabular}{|c|c|c|c|}
\hline No. & Responden & Pertanyaan & Jawaban \\
\hline \multirow{29}{*}{10.} & HY (L) P2K & \multirow{29}{*}{$\begin{array}{l}\text { Kendala apa saja } \\
\text { yang dirasakan bila } \\
\text { berinteraksi dengan } \\
\text { pustakawan di LIPI }\end{array}$} & 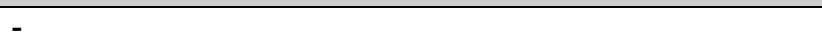 \\
\hline & $\mathrm{T}(\mathrm{L}) \mathrm{P} 2 \mathrm{~K}$ & & - \\
\hline & As $(\mathrm{P}) \mathrm{P} 2 \mathrm{~K}$ & & - \\
\hline & $\mathrm{D}(\mathrm{P}) \mathrm{P} 2 \mathrm{~K}$ & & - \\
\hline & $\mathrm{BS}(\mathrm{L}) \mathrm{P} 2 \mathrm{~K}$ & & - \\
\hline & FN (L) P2P & & - \\
\hline & AR (L) P2P & & - \\
\hline & Sa (P) P2P & & - \\
\hline & $\mathrm{Al}(\mathrm{P}) \mathrm{P} 2 \mathrm{P}$ & & - \\
\hline & $\mathrm{T}(\mathrm{L}) \mathrm{P} 2 \mathrm{P}$ & & - \\
\hline & Aan (L) P2O & & - \\
\hline & $\mathrm{Rd}(\mathrm{L}) \mathrm{P} 2 \mathrm{O}$ & & - \\
\hline & HT (L) P2O & & - \\
\hline & Rh (P) BMR & & - \\
\hline & SSP (P) PMB & & - \\
\hline & WMS (P) PMB & & Pustakawan tidak melayani dengan baik. \\
\hline & NW (P) PMB & & \\
\hline & AW (P) PMB & & $\begin{array}{l}\text { Pustakawan kurang menguasai bidangnya dan tidak } \\
\text { mampu memenuhi kebutuhan peneliti sebagai } \\
\text { usernya. }\end{array}$ \\
\hline & GW (P) PSDR & & $\begin{array}{l}\text { Tidak selalu berada di tempat, sehingga ketika } \\
\text { dibutuhkan tidak ada. }\end{array}$ \\
\hline & MK (L) PSDR & & $\begin{array}{l}\text { PDII tidak memiliki pustakawan ekspertis dengan } \\
\text { kata lain Pustakawan PDII tidak memiliki } \\
\text { kemampuan spesifik menangani topik/bidang/isu-isu } \\
\text { tertentu yang dikerjakan para peneliti. }\end{array}$ \\
\hline & MP (P) PSDR & & Pustakawan kurang membantu dengan baik \\
\hline & ET (P) PSDR & & $\begin{array}{l}\text { Pustakawan sudah baik. } \\
\text { Kurangnya jumlah pustakawan yg melayani. }\end{array}$ \\
\hline & $\mathrm{AE}(\mathrm{L}) \mathrm{P} 2 \mathrm{E}$ & & Pelayanan kurang ramah. \\
\hline & TE (P) P2E & & - \\
\hline & IS (L) P2E & & - \\
\hline & S (L) P2E & & Belum memahami tugasnya \\
\hline & RF (L) Papiptek & & - \\
\hline & $\begin{array}{l}\text { SM (L) } \\
\text { Papiptek }\end{array}$ & & - \\
\hline & LA (P) Papiptek & & - \\
\hline
\end{tabular}




\begin{tabular}{|c|c|c|c|}
\hline No. & Responden & Pertanyaan & Jawaban \\
\hline \multirow{21}{*}{11.} & HY (L) P2K & \multirow{21}{*}{$\begin{array}{l}\text { Harapan terhadap } \\
\text { keberadaan } \\
\text { perpustakaan di LIPI }\end{array}$} & 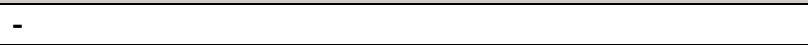 \\
\hline & $\mathrm{T}(\mathrm{L}) \mathrm{P} 2 \mathrm{~K}$ & & - \\
\hline & As $(\mathrm{P}) \mathrm{P} 2 \mathrm{~K}$ & & - \\
\hline & $\mathrm{D}(\mathrm{P}) \mathrm{P} 2 \mathrm{~K}$ & & - \\
\hline & BS (L) P2K & & - \\
\hline & FN (L) P2P & & - \\
\hline & AR (L) P2P & & - \\
\hline & Sa $(P) P 2 P$ & & - \\
\hline & $\mathrm{Al}(\mathrm{P}) \mathrm{P} 2 \mathrm{P}$ & & - \\
\hline & $\mathrm{T}(\mathrm{L}) \mathrm{P} 2 \mathrm{P}$ & & - \\
\hline & Aan (L) P2O & & - \\
\hline & $\mathrm{Rd}(\mathrm{L}) \mathrm{P} 2 \mathrm{O}$ & & - \\
\hline & HT (L) P2O & & - \\
\hline & Rh (P) BMR & & - \\
\hline & SSP (P) PMB & & $\begin{array}{l}\text { Tetap menyimpan koleksi lama dengan menjaga } \\
\text { fisik bukunya maupun dialihmediakan dalam bentuk } \\
\text { digital, pengadaan koleksi berdasarkan usulan di } \\
\text { masing-masing puslit, menginformasikan kembali } \\
\text { kepada pengusul mengenai status usulan koleksi } \\
\text { yang diusulkan peneliti, koleksi jurnal diperbanyak } \\
\text { dan gratis mengunduh, ada ruang diskusi, semua } \\
\text { koleksi terintegrasi dan dapat diakses online, dapat } \\
\text { diakses dimanapun, buku cetak yang terbaru, } \\
\text { terdapat ruangan dan bahan untuk menjamu dan } \\
\text { memamerkan kepada tamu-tamu peneliti yang } \\
\text { datang ke LIPI. }\end{array}$ \\
\hline & WMS (P) PMB & & $\begin{array}{l}\text { Tersedianya kurator. (yang ahli dalam penelusuran } \\
\text { koleksi, menghafal semua koleksi), memiliki } \\
\text { software yang digunakan peneliti. }\end{array}$ \\
\hline & NW (P) PMB & & $\begin{array}{l}\text { Koleksi dan layanan dapat diakses dimana saja, } \\
\text { memperbarui koleksi sesuai dengan isu-isu, } \\
\text { memperkaya koleksi buku-buku lama yang bersifat } \\
\text { penting dalam bentuk digital, layanan dan fasilitas } \\
\text { disesuaikan dengan perilaku dan kebutuhan dan } \\
\text { harus bisa mengikuti isu dan teknik pelayanan yang } \\
\text { dibutuhkan, diberikan ruang diskusi untuk peneliti. }\end{array}$ \\
\hline & $\mathrm{AW}(\mathrm{P}) \mathrm{PMB}$ & & $\begin{array}{l}\text { Ada revitalisasi terhadap pelayanan, fasilitas, } \\
\text { sarana prasarana. }\end{array}$ \\
\hline & GW (P) PSDR & & $\begin{array}{l}\text { Menyediakan buku-buku yang saling berkaitan } \\
\text { dalam pembahasannya } \\
\text { Terdapat pengadaan/pembelian buku dengan } \\
\text { sistem yang fleksibel. Peneliti dapat membeli buku } \\
\text { dan dapat di-reimburse. } \\
\text { Perpustakaan harus dinamis. }\end{array}$ \\
\hline & MK (L) PSDR & & $\begin{array}{l}\text { Perpustakaan dengan suasana seperti di café. } \\
\text { Perpustakaan memberikan pelayanan secara fisik } \\
\text { dan digital }\end{array}$ \\
\hline & MP (P) PSDR & & $\begin{array}{l}\text { Memperbarui koleksi rujukan terutama yang } \\
\text { memuat profil dan sejarah suatu negara, } \\
\text { pemberitahuan koleksi yang dimiliki Perpustakaan } \\
\text { kepada peneliti, menyediakan koleksi tercetak, } \\
\text { memberikan literatur, dilengkapi dengan fasilitas- } \\
\text { fasilitas yang dibutuhkan peneliti. }\end{array}$ \\
\hline
\end{tabular}


Lanjutan...

\begin{tabular}{|c|c|c|c|}
\hline No. & Responden & Pertanyaan & Jawaban \\
\hline \multirow[t]{8}{*}{ 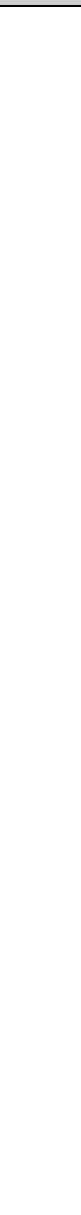 } & ET (P) PSDR & & $\begin{array}{l}\text { Koleksi buku tetap ada, koleksi bertambah dan } \\
\text { terbarukan, bisa membantu peneliti untuk } \\
\text { menyalurkan bukunya ke narasumber, memenuhi } \\
\text { kebutuhan buku para peneliti dalam bentuk tercetak. }\end{array}$ \\
\hline & AE (L) P2E & & $\begin{array}{l}\text { Nuansanya harus seperti living room of community, } \\
\text { koleksi digital seharusnya seimbang dengan yang } \\
\text { non-digital, kalau sudah ada digital tidak perlu ada } \\
\text { printed-nya, untuk ilmu sosial, koleksi-koleksi klasik } \\
\text { (buku lama yang mengandung teori } \\
\text { babon/utama/induk) tetap harus ada, memajang } \\
\text { hasil karya dan alat-alat/instrumen/koleksi penelitian } \\
\text { para peneliti hebat LIPI yang dulu digunakan } \\
\text { sehingga menjadikan mereka peneliti besar. }\end{array}$ \\
\hline & TE (P) P2E & & $\begin{array}{l}\text { Perpustakaan (koleksi) PDII bisa diakses dimana } \\
\text { saja, sebagai rujukan nasional, memiliki koleksi- } \\
\text { koleksi terbaru, perpustakaan PDII harus } \\
\text { mempunyai nilai unggul. }\end{array}$ \\
\hline & IS (L) P2E & & $\begin{array}{l}\text { Menjadi induk dari perpustakaan di satker. menjamu } \\
\text { tamu peneliti yang datang, memberikan layanan } \\
\text { kunjungan perpustakaan dengan memberikan } \\
\text { konten perpustakaan yang bagus. }\end{array}$ \\
\hline & S (L) P2E & & Fasilitas dan koleksi perpustakaan ditingkatkan \\
\hline & $\begin{array}{l}\text { RF (L) } \\
\text { Papiptek }\end{array}$ & & Suasana agar lebih nyaman \\
\hline & $\begin{array}{l}\text { SM (L) } \\
\text { Papiptek }\end{array}$ & & $\begin{array}{l}\text { Dibuat seperti co-working space, diadakannya kartu } \\
\text { akses yang bisa dimanfaatkan peneliti LIPI } 24 \text { jam, } \\
\text { disediakan fasilitas-fasilitas penunjang, opac yang } \\
\text { ramah }\end{array}$ \\
\hline & $\begin{array}{l}\text { LA (P) } \\
\text { Papiptek }\end{array}$ & & - \\
\hline
\end{tabular}




\begin{tabular}{|c|c|c|c|}
\hline No. & Responden & Pertanyaan & Jawaban \\
\hline & HY (L) P2K & \multirow{27}{*}{$\begin{array}{l}\text { Harapan terhadap } \\
\text { keberadaan } \\
\text { pustakawan di LIPI }\end{array}$} & - \\
\hline & $\mathrm{T}(\mathrm{L}) \mathrm{P} 2 \mathrm{~K}$ & & - \\
\hline & As (P) P2K & & - \\
\hline & $\mathrm{D}(\mathrm{P}) \mathrm{P} 2 \mathrm{~K}$ & & - \\
\hline & BS (L) P2K & & - \\
\hline & FN (L) P2P & & - \\
\hline & AR (L) P2P & & - \\
\hline & Sa (P) P2P & & - \\
\hline & $\mathrm{Al}(\mathrm{P}) \mathrm{P} 2 \mathrm{P}$ & & - \\
\hline & $\mathrm{T}(\mathrm{L}) \mathrm{P} 2 \mathrm{P}$ & & - \\
\hline & Aan (L) P2O & & - \\
\hline & $\mathrm{Rd}(\mathrm{L}) \mathrm{P} 2 \mathrm{O}$ & & - \\
\hline & HT (L) P2O & & - \\
\hline & $\mathrm{Rh}(\mathrm{P}) \mathrm{BMR}$ & & - \\
\hline & SSP (P) PMB & & $\begin{array}{l}\text { Pustakawan memiliki ekpertis atau kepakaran di } \\
\text { bidang/topik/isu-isu }\end{array}$ \\
\hline & WMS (P) PMB & & $\begin{array}{l}\text { Harapan utk pustakawan adalah dapat membangun } \\
\text { hubungan kolegial dengan peneliti. Kerja sama dalam } \\
\text { kepenulisan, berusaha berintegrasi lagi dengan } \\
\text { lembaga lain, menguasai dan memiliki software yang } \\
\text { digunakan peneliti, pustakawan mengadakan } \\
\text { pelatihan/pendidikan pemustaka. Misal tentang } \\
\text { penggunaan software pendukung penelitian, } \\
\text { Pustakawan mengadakan FGD misalnya membangun } \\
\text { kerjasama antara pustakawan dan peneliti dengan } \\
\text { tujuan untuk membangun ide, mempertahankan } \\
\text { koleksi perempuan dan anak. Caranya dengan } \\
\text { mengadakan seminar yang mengundang Komisi } \\
\text { perlindungan Anak untuk mempertahankan koleksi } \\
\text { perempuan dan anak, pustakawan diusulkan untuk } \\
\text { masuk di dalam tulisan ilmiah hasil kolaborasi dengan } \\
\text { peneliti di satker, pustakawan harus tau laman } \\
\text { (website) penting sebagai sumber rujukan. }\end{array}$ \\
\hline & NW (P) PMB & & $\begin{array}{l}\text { Pengetahuan pustakawan dikembangkan sesuai } \\
\text { dengan pengembangan koleksi }\end{array}$ \\
\hline & $\mathrm{AW}(\mathrm{P}) \mathrm{PMB}$ & & $\begin{array}{l}\text { Pustakawan dapat menguasai berbagai hal dan } \\
\text { mampu memenuhi kebutuhan peneliti }\end{array}$ \\
\hline & GW (P) PSDR & & $\begin{array}{l}\text { Mengubah mindset, memiliki visi dan misi untuk } \\
\text { membawa perpustakaan ke era } 4.0\end{array}$ \\
\hline & MK (L) PSDR & & Layanan tidak kaku. \\
\hline & MP (P) PSDR & & $\begin{array}{l}\text { Pustakawan yang siaga membantu, ramah, menguasai } \\
\text { literatur, mempromosikan/mendiseminasikan hasil } \\
\text { penelitian peneliti LIPI dengan menawarkannya } \\
\text { kepada pengunjung perpustakaan. }\end{array}$ \\
\hline & ET (P) PSDR & & - \\
\hline & AE (L) P2E & & SDM dari pustakawan ditingkatkan \\
\hline & TE (P) P2E & & Menginovasi layanan \\
\hline & IS (L) P2E & & $\begin{array}{l}\text { Pustakawan memiliki kemampuan di bidang yang } \\
\text { tersedia sekarang }\end{array}$ \\
\hline & S (L) P2E & & $\begin{array}{l}\text { Orofesional, mengetahui tugas masing-maisng, } \\
\text { membantu dan mempermudah user }\end{array}$ \\
\hline & $\begin{array}{l}\text { RF (L) } \\
\text { Papiptek }\end{array}$ & & $\begin{array}{l}\text { Menguasai dan mampu menjawab semua pertanyaan } \\
\text { pemustaka, mampu memberikan tinjauan literatur dan } \\
\text { ringkasan, mampu memberikan saran dan } \\
\text { rekomendasi jurnal yang sesuai dengan topik, dan } \\
\text { jurnal yang dibutuhkan }\end{array}$ \\
\hline \multirow{2}{*}{12.} & $\begin{array}{l}\text { SM (L) } \\
\text { Papiptek }\end{array}$ & & $\begin{array}{l}\text { Memberikan pelayanan yang memuaskan, } \\
\text { memberikan pelayanan yang memuaskan }\end{array}$ \\
\hline & $\begin{array}{l}\text { LA (P) } \\
\text { Papiptek }\end{array}$ & & - \\
\hline
\end{tabular}

